\section{Re: Hvor går grensen mellom diagnostikk og forskning?}

I artikkelen «Hvor går grensen mellom diagnostikk og forskning?» i Tidsskriftet (1) tar Gunnar Houge opp en viktig problemstilling knyttet til genetisk utredning og forskning: Hvor går grensen mellom diagnostisk utredning for å finne den genetiske forklaringen på en tilstand, for eksempel et utviklingsavvik, og klinisk forskning der målet er å få ny kunnskap?

Houge beskriver en klinisk situasjon som vi etterhvert kjenner godt: En person er til utredning ved medisinskgenetisk avdeling fordi det er mistanke om at tilstanden eller sykdommen hans/hennes skyldes en gen- eller kromosomfeil. Denne kan være nyoppstått, eller den kan være nedarvet. I mange tilfeller, for eksempel ved utviklingsavvik, passer ikke de aktuelle trekkene ved avviket eller symptomene ved sykdommen med en kjent gen- eller kromosomfeil. Andre ganger passer det nesten med en kjent tilstand, men genanalysen gir ikke treff på noen av de genene man vet kan være årsak. Da må man, som Houge beskriver, bruke metoder som sjekker større deler av genomet. I noen tilfeller vil man finne at årsaken til tilstanden eller sykdommen ligger i et kjent «sykdomsgen». I andre tilfeller gjøres det funn som ikke tidligere er beskrevet, men som sannsynligvis er årsak til tilstanden eller sykdommen. Dette må bekreftes med videre undersøkelser, for eksempel at det gjøres flere undersøkelser av pasienten og/eller tas prøver av familiemedlemmer for å avklare om tilstanden eller sykdommen er nedarvet.

Gunnar Houge skriver: «Etter mitt syn er ikke det å gjøre et uventet og nytt funn forskning. Funnet innebærer i seg selv ingen «ny viten om helse og sykdom»- men det har potensial til å gjøre det. Oppfølgingen - ikke funnet - er derimot forskning - og da menes oppfølging utover rutinemessig avklarende diagnostisk utredning. Det samme gjelder dersom funnet slås sammen med liknende funn hos andre slik at man har et pasientmateriale som beskriver en ny tilstand.»

Helsedirektoratet har fortolkningsansvar for helseforskningsloven og bioteknologiloven, som begge er aktuelle her. Vi er enige i Houges vurdering: All klinisk utredning for å finne en ny genetisk årsak til en sykdom eller tilstand er ikke forskning.

Til spørsmål om hvor grensen går: Undersøkelser som gjøres av pasienten selv eller nærmeste familie for å bekrefte funn eller styrke «mistanken» om arvelig sykdom, oppfatter vi som en del av utredningen. Dette er vanlig rutine ved de medisinskgenetiske avdelingene. Når det gjøres genetiske undersøkelser på (presumtivt friske) familiemedlemmer, vil bioteknologiloven gjelde, og de som undersøkes har krav på genetisk veiledning og det må innhentes samtykke.

I noen tilfeller kan funnet være så interessant at man velger å gjøre bredere undersøkelser. Foreligger det f.eks. informasjon om flere pasienter som kan tenkes å ha den aktuelle tilstanden, vil det være aktuelt å samle inn og genteste materiale fra dem og deres familier. Da er det etter vårt syn ikke lenger en klinisk utredning, men et klinisk forskningsprosjekt. Helseforskningsloven gjelder, og prosjektet må vurderes og godkjennes av REK. Slike prosjekter vil også være omfattet av bioteknologiloven fordi resultatene har diagnostiske eller behandlingsmessige konsekvenser for deltakerne, og i tillegg får deltakerne (etter all sannsynlighet) tilbakemelding om resultatene, dersom de ønsker det.

\section{Anne Forus}

anne.forus@helsedir.no

Kristin Cordt-Hansen

Anne Forus (f. 1964) er seniorrådgiver i Helsedirektoratet.

Ingen oppgitte interessekonflikter.

Kristin Cordt-Hansen (f. 1962) er avdelingsdirektør i Helsedirektoratet. Ingen oppgitte interessekonflikter.

\section{Litteratur}

1. Houge G. Hvor går grensen mellom diagnostikk og forskning? Tidsskr Nor Legeforen - Publisert først på nett 15. september 2015.

\section{Re: Øyeblikkeleg hjelp-døgnopphald i seks kommunar på Sunnmøre}

Takk for en interessant artikkel om øyeblikkelig hjelp-døgnopphold (ØHD) i Tidsskriftet nr. 17/2015 (1). Det er interessant med kommuner som går «mot strømmen» og etablerer tilbud i egen kommune. Noe av formålet med ØHD-plassene var jo å etablere et tilbud nærmere pasientens bosted og nærmiljø. Det er ikke alltid tilfellet i interkommunale ordninger. I Hamar-området må mange av pasientene faktisk reise forbi sykehuset for å komme til de lokale ØHD-sengene.

Pasienter som legges inn i ØHD skal være pasienter som ellers ville blitt lagt inn i sykehus. Dette spørsmålet er lite berørt i artikkelen. Mitt spørsmål er om det tilbudet disse kommunene har etablert er «ordentlige» ØHD-senger, eller om det mer er et slags forsterket sykehjem. Nysgjerrigheten på dette ble vakt da jeg i artikkelen leste sitatet fra den erfarne legen som uttalte at ØHD-senger er et sykepleiefaglig tilbud, og at dersom pasienten hadde behov for legetilsyn flere ganger i døgnet, var ikke ØHD rette plassen (1). Et annet sted står det at studien ikke kan si noe om hvor mange av pasientene som ville blitt lagt inn i sykehus dersom ØHD ikke fantes.

Spørsmålet jeg sitter igjen med blir derfor om denne artikkelen $i$ bunn og grunn handler om ØHD-senger, eller om den handler om et annet (fint) tilbud disse kommunene har etablert?

\section{Sven Anders Haugtomt \\ sven.anders@haugtomt.no}

Sven Anders Haugtomt (f. 1953) er pensjonist og var tidligere assisterende fylkeslege i Hedmark.

Ingen oppgitte interessekonflikter

\section{Litteratur}

1. Hole T, Barstad J, Teigen S et al. Øyeblikkeleg hjelp-døgnopphald i seks kommunar på Sunnmøre. Tidsskr Nor Legeforen 2015; 135: 1553-7.

\section{T. Hole og medarbeidarar svarar:}

Takk for ein svært relevant merknad til vår artikkel. Dette er ei hovudproblemstilling for desse ØHD-sengene. Tilbodet skal vere eit alternativ til innlegging i sjukehus, og med minst like god kvalitet (for pasienten). Sitatet frå legen må ikkje trekkast for langt; det er faktisk diagnostisk tilbod i sengene slik vi erfarer det, og styrka legeteneste slik at fast lege er tilgjengeleg på dagtid med beredskap ettermidddag for dei fleste tilboda, og tilgang legevakt helg/natt. Men svært overvakingskrevjande pasientar, som krev hyppige legetilsyn gjennom heile døgnet, vil ikkje vere eigna for dette tilbodet. Kriteriene for innlegging i desse kommunane er at problemstillinga $i$ hovudsak er avklart før innlegging. Vi vonar at vi i løpet av nokre få år kan ha gode data som også kan gje svar på denne svært viktige problemstillinga.

\section{Torstein Hole \\ torstein.hole@helse-mr.no \\ Johan Barstad \\ Solfrid Teigen \\ Marit Kvangarsnes}

Torstein Hole (f. 1957) er spesialist $\mathrm{i}$ indremedisin og i hjertesykdommer og klinikksjef ved Ålesund sjukehus og førsteamanuensis II ved medisinsk fakultet, NTNU.

Ingen oppgitte interessekonflikter.

Johan Barstad (f. 1956) er samfunnsøkonom, seniorforsker og forskingsrådgiver ved Forskingsseksjonen Helse Møre og Romsdal HF. Ingen oppgitte interessekonflikter.

Solfrid Teigen (f. 1953) er sykepleier ved helse- og sosialavdelinga, Volda kommune og koordinator i ledernettverk for helse- og omsorgsledere i kommunene på Søre Sunnmøre. Ingen oppgitte interessekonflikter. 
Marit Kvangarsnes (f. 1956) er professor i sjukepleie og i pedagogikk ved Høgskulen i Ålesund og forskingsveileder ved Forskingsseksjonen Helse Møre og Romsdal HF.

Ingen oppgitte interessekonflikter.

\section{Re: Førstegangs generalisert tonisk-klonisk krampeanfall}

I oversiktsartikkelen «Førstegangs generalisert tonisk-klonisk krampeanfall» i Tidsskriftet nr. 14/2015 (1) konkluderer forfatterne med at man skal avvente med behandling etter ett anfall. Jeg savner en diskusjon om hvordan man skal forholde seg til alvorlige komplikasjoner som død når man utsetter oppstart av behandling. Død forekommer i epilepsi, både som komplikasjon til anfall og som SUDEP (sudden unexpected death in epilepsy) $(2,3)$. Den viktigste muligheten man har for å forebygge død ved epilepsi, er god anfallskontroll. Når man avventer behandling, utsetter man pasientene for alvorlige komplikasjoner som død i ventetiden.

Man kan argumentere med at dødsfall ved epilepsi er sjeldent. $\mathrm{Ja}$, det er sjeldent. Forekomsten av plutselig og uventet død blant pasienter med velkontrollert epilepsi er estimert til ca. 1/1 000, sannsynligvis 30-40 tilfeller i året i Norge (2). SUDEP kan ramme når som helst, oftest hos unge mennesker, gjerne ved bytte av medisiner, endring av doser osv., men også ved stabil behandling over lang tid. Og det kan selvfølgelig forekomme i utredningstiden. Det er en utfordring at dødsfall ved epilepsi er så sjeldent at man ikke vil klare å lage store nok studier til statistisk å kunne belyse dette. Man er derfor nødt til å forholde seg til dette på annen måte. Litteraturen om SUDEP understreker viktigheten av god anfallsforebyggende behandling (3). Dette er kanskje den eneste muligheten man i øyeblikket har for å forebygge SUDEP, muligens i tillegg til epilepsialarmer. Jeg synes dette burde ha vært drøftet i artikkelen.
Et annet viktig moment jeg savner i artikkelen, er en diskusjon om informasjon. Alltid, både når man starter opp med medikamentell behandling og kanskje enda viktigere når man avventer, er god informasjon viktig. Ut fra min personlige erfaring, har jeg en opplevelse av at man under utredning av epilepsi har den holdningen at pasient og pårørende ikke skal uroes, og derfor skal ha minst mulig informasjon om epilepsi. Dette er jeg sterkt uenig i. Man skal selvfølgelig ikke uroe pasienter unødig, men det er helt avgjørende å gi god nok informasjon til at pårørende kan håndtere eventuelle anfallssituasjoner i ventetiden, også dersom det viser seg at pasienten har en alvorlig form for epilepsi. Det er utrolig viktig å sørge for at pårørende ikke sitter igjen med en følelse av at de kunne ha gjort mer, dersom de hadde fått bedre informasjon i tilfeller med SUDEP eller andre alvorlige hendelser i den tiden man avventer behandling. Intervjuer av etterlatte ved blant annet SUDEP presiserer ønsket om informasjon om SUDEP (4).

\section{Ingebjørg Skrindo}

ingebjorg.skrindo@medisin.uio.no

Ingebjørg Skrindo (f. 1970) er overlege ved Øre-nese-hals avdelingen, Akershus Universitetssykehus.

Ingen oppgitte interessekonflikter.

\section{Litteratur}

1. Realfsen MS, $\mathrm{B} \varnothing \mathrm{SMH}$, Lossius MI et al. Førstegangs generalisert tonisk-klonisk krampeanfall. Tidsskr Nor Legeforen 2015; 135: 1256-8.

2. Lossius R, Nakken KO. Epilepsi og plutselig død. Tidsskr Nor Lægeforen 2002; 122: $1114-7$

3. Verma A, Kumar A. Sudden unexpected death in epilepsy: some approaches to prevent it. J Neuropsychiatry Clin Neurosci 2015; 27: e28-31.

4. Stevenson MJ, Stanton TF. Knowing the risk of SUDEP: two family's perspectives and The Danny Did Foundation. Epilepsia 2014; 55: 1495-500. 